\title{
原著
}

\section{多群モデルにおけるすべての平均相違に関する閉検定手順 \\ Closed Testing Procedures for Pairwise Comparisons in Multi-Sample Models}

\author{
白石高章 \\ Taka-aki Shiraishi \\ 南山大学情報理工学部 \\ Faculty of Information Sciences and Engineering, Nanzan University \\ e-mail:marble@nanzan-u.ac.jp
}

\begin{abstract}
Under the assumptions of the continuous distribution and equality of variance, we consider multiple comparisons tests for the differences among mean responses in $k$ samples. Closed testing procedures are superior to the Tukey-Kramar type multiple tests which are single-step procedures in many cases. The closed testing procedure more powerful than the Tukey-Welsch test and the REGW test is proposed under the usual normality. Furthermore the nonparametric closed testing procedure is discussed based on ranks. Last the proposed nonparametric closed testing procedure is illustrated with data regarding sarcoidosis from the assay of serum angiotensin-converting enzyme (SACE).
\end{abstract}

Key words: Multiple comparisons tests, Tukey-Kramar test, Nonparametric rank tests, Family-wise error rate, Asymptotic theory.

\section{1. はじめに}

分散の等しい正規分布を仮定した多群モデルにおけるすべての平均相違の多重比較検定法が, Tukey (1953) と Kramer (1956) によって提案され, 現在ではテューキー・クレーマー (TukeyKramer) 法とよばれている. 2 群間の $t$ 検定統計量を $t_{i i^{\prime}}$ とするとき, $\max _{i<i^{\prime}}\left|t_{i i^{\prime}}\right|$ の分布が， ス チューデント化された範囲の $\sqrt{2}$ 倍の統計量の分布によって下から抑えられることを, Hayter (1984) は示した. 長年正しいとされていた $\max _{i<i^{\prime}}\left|t_{i i^{\prime}}\right|$ の正確な分布は, 実際は $\max _{i<i^{\prime}}\left|t_{i i^{\prime}}\right|$ の 分布を上から抑える分布であることを, 白石 (2006) は証明した. 白石 (2006) は, これらの不等 式と数值積分を利用して, Tukey-Kramer 法の保守度を調べることできた.

正規分布の下でのテューキー・クレーマー型多重比較検定を発展させた手法として, 永田・吉 田 (1997) で紹介されているテューキー・ウェルシュの方法と丹後・小西 (2010) で紹介されている REGW 法が閉検定手順として知られている. これらの閉検定手順よりも一様に検出力が高い閉検 定手順を提案する. 閉検定手順が正当であるための条件としてシダック (Šidák)の不等式をあげて

Received December 2010. Revised January 2011. Accepted January 2011. 
表 $1 . \quad k$ 群モデル

\begin{tabular}{|c|c|c|c|c|}
\hline 群 & サイズ & データ & 平均 & 分布関数 \\
\hline 第 1 群 & $n_{1}$ & $X_{11}, \cdots, X_{1 n_{1}}$ & $\mu_{1}$ & $F\left(x-\mu_{1}\right)$ \\
\hline 第 2 群 & $n_{2}$ & $X_{21}, \cdots, X_{2 n_{2}}$ & $\mu_{2}$ & $F\left(x-\mu_{2}\right)$ \\
\hline$\vdots$ & : & $\vdots \quad \vdots$ & : & : \\
\hline 第 $k$ 群 & $n_{k}$ & $X_{k 1}, \cdots, X_{k n_{k}}$ & $\mu_{k}$ & $F\left(x-\mu_{k}\right)$ \\
\hline
\end{tabular}

総標本サイズ $: n \equiv n_{1}+\cdots+n_{k}$ (すべての観測值の個数） $\mu_{1}, \cdots, \mu_{k}$ はすべて 未知パラメータとする.

いる教本が多いが，正則条件が明確でない，このため，この論文には，正当性 (validity)の正則条 件を明解にするために, 補題 1 とその証明を与えている. 補題 1 を利用すれば, テューキー・ウェ ルシュの方法も REGW 法も閉検定手順として正当であることが解る. 補題 1 は Kimball (1951) の定理を拡張したものである.

テューキー・クレーマー法は, 正規分布の下でのパラメトリック法であるが, このパラメトリッ ク法に対応して, 分布に依らないノンパラメトリック多重比較検定法として, スティール (Steel (1960))，ドゥワス (Dwass (1960))によって，2 群間のウィルコクソンの順位和に基づく多重比較 検定法が提案された. 全体順位を使う順位統計量に基づくノンパラメトリック多重比較検定法を ダン(Dunn (1964))が提案しているが, Oude Voshaar (1980) とHsu (1996) は, ダンの方法が多 重比較検定になっていないことを指摘している. ノンパラメトリック多重比較では, 全体順位で はなく 2 群間の中での順位を使う方法が正しい.すべての母平均差に対して，2 群間の中での順 位を使う分布に依存しないノンパラメトリック同時信頼区間の理論が白石 (2006) によって構築さ れた。

正規分布の下での閉検定手順と同様に， 2 群間のウィルコクソンの順位和に基づくノンパラメ トリック閉検定手順を提案し, 漸近理論を構築する.

最後に, 提案したノンパラメトリック閉検定手順を使って, 肉芽種病のデータを解析する.

\section{2. モデルの設定と多重比較検定の定義}

ある要因 $A$ があり, $k$ 個の水準 $A_{1}, \ldots, A_{k}$ を考える. 水準は群ともよばれる. 水準 $A_{i}$ におけ る標本の観測值 $\left(X_{i 1}, X_{i 2}, \cdots, X_{i n_{i}}\right)$ は第 $i$ 標本または第 $i$ 群とよばれ, 平均が $\mu_{i}$ である同一の連 続型分布関数 $F\left(x-\mu_{i}\right)$ をもつとする. すなわち,

$$
P\left(X_{i j} \leqq x\right)=F\left(x-\mu_{i}\right), \quad E\left(X_{i j}\right)=\mu_{i} .
$$

$f(x) \equiv F^{\prime}(x)$ とおくと, $\int_{-\infty}^{\infty} x f(x) d x=0$ が成り立つ. さらにすべての $X_{i j}$ は互いに独立である と仮定する. 総標本サイズを $n \equiv n_{1}+\cdots+n_{k}$ とおく. 標本とその平均, 分布関数を表 1 に載せ ている.

$k$ 個の水準の平均パラメータのすべての比較を考える.

1 つの比較のための検定は

帰無仮説 $H_{\left(i, i^{\prime}\right)}: \mu_{i}=\mu_{i^{\prime}}$ vs. 対立仮説 $H_{\left(i, i^{\prime}\right)}^{A}: \mu_{i} \neq \mu_{i^{\prime}}$ 
となる．帰無仮説のファミリーを，

$$
\mathcal{H} \equiv\left\{H_{(1,2)}, H_{(1,3)}, \cdots, H_{(1, k)}, H_{(2,3)}, \cdots, H_{(2, k)}, \cdots, H_{(k-1, k)}\right\}
$$

とおく. 便宜上, 一様性の帰無仮説を

$$
H_{0}: \mu_{1}=\cdots=\mu_{k}
$$

とする.

定数 $\alpha(0<\alpha<1)$ をはじめに決める.

$\boldsymbol{X} \equiv\left(X_{11}, \cdots, X_{1 n_{1}}, \cdots, X_{k 1}, \cdots, X_{k n_{k}}\right)$ の実現值 $\boldsymbol{x}$ によって, 任意の $H_{a} \in \mathcal{H}$ に対して $H_{a}$ を 棄却するかしないかを決める検定方式を $\phi_{a}(\boldsymbol{x})$ とする.

$\boldsymbol{\mu} \equiv\left(\mu_{1}, \cdots, \mu_{k}\right)$ とおく.すべての $1 \leqq i<i^{\prime} \leqq k$ に対して, $\mu_{i} \neq \mu_{i^{\prime}}$ のときは, 有意水準は関 係しないので,

$$
\begin{aligned}
\Theta_{0} & \equiv\left\{\boldsymbol{\mu} \mid 1 \text { つ以上の帰無仮説 } H_{\left(i, i^{\prime}\right)} \text { が真 }\right\} \\
& =\left\{\boldsymbol{\mu} \mid \text { ある } i<i^{\prime} \text { に対して } \mu_{i}=\mu_{i^{\prime}}\right\}
\end{aligned}
$$

とおき, $\boldsymbol{\mu} \in \Theta_{0}$ とする. このとき, 正しい帰無仮説 $H_{\left(i, i^{\prime}\right)}$ は 1 つ以上ある. また, 確率は $\boldsymbol{\mu}$ に 依存するので, 確率測度を $P_{\mu}(\cdot)$ で表わす.

このとき，すべての $\boldsymbol{\mu} \in \Theta_{0}$ に対して

$$
\left.P_{\mu} \text { (正しい帰無仮説のうち少なくとも } 1 \text { つが棄却される }\right) \leqq \alpha
$$

を満たす検定方式 $\left\{\phi_{a}(\boldsymbol{x})\right\}$ を, H に対する水準 $\alpha$ の多重比較検定法とよんでいる. (2) の左辺を, ( $\boldsymbol{\mu}$ を固定したときの)第 1 種の過誤の確率またはタイプ I FWER (type I familywise error rate) とよぶ. また，(2) の右辺の $\alpha$ は全体としての有意水準である. すべての $\boldsymbol{\mu} \in \Theta_{0}$ に対して (2) が 成り立つことは,

$$
\sup _{\mu \in \Theta_{0}}((2) \text { の左辺 }) \leqq \alpha
$$

と同值である. すなわち, タイプ I FWER の上限が $\alpha$ 以下である必要がある.

\section{3. テューキー・クレーマー(Tukey-Kramer)の方法}

パラメトリック手法を紹介する. $F(x)$ を正規分布 $N\left(0, \sigma^{2}\right)$ の分布関数とする. 分散 $\sigma^{2}$ は未知 とする. このとき, 多重比較検定と同時推定を行うために, 分布関数 $T A(t), T B(t)$ を紹介する.

$$
\begin{aligned}
& T A(t) \equiv k \int_{0}^{\infty}\left[\int_{-\infty}^{\infty}\{\Phi(x)-\Phi(x-\sqrt{2} \cdot t s)\}^{k-1} d \Phi(x)\right] g(s) d s, \\
& T B(t) \equiv \sum_{j=1}^{k} \int_{0}^{\infty}\left[\int_{-\infty}^{\infty} \prod_{\substack{i=1 \\
i \neq j}}^{k}\left\{\Phi\left(\frac{\sqrt{\lambda_{n i}} \cdot x}{\sqrt{\lambda_{n j}}}\right)-\Phi\left(\frac{\sqrt{\lambda_{n i}} \cdot x}{\sqrt{\lambda_{n j}}}-\frac{\sqrt{\lambda_{n i}+\lambda_{n j}} \cdot t s}{\sqrt{\lambda_{n j}}}\right)\right\} d \Phi(x)\right] g(s) d s .
\end{aligned}
$$

ただし, $\lambda_{n i} \equiv n_{i} / n(i=1, \cdots, k)$,

$$
g(s) \equiv \frac{m^{m / 2}}{\Gamma(m / 2) 2^{(m / 2-1)}} s^{m-1} \exp \left(-m s^{2} / 2\right)=\frac{m s e^{-s^{2}} c^{(m / 2-1)}}{\Gamma(m / 2)},
$$

Jpn J Biomet Vol. 32, No. 1, 2011 


$$
c \equiv m s^{2} e^{-s^{2}} / 2, \quad m \equiv n-k
$$

とする.

$\alpha$ を与え,

$$
\text { 方程式 } T A(t)=1-\alpha \text { を満たす } t \text { の解を } t a(k, m ; \alpha)
$$

とおく.

帰無仮説 $H_{\left(i, i^{\prime}\right)}$ と対立仮説 $H_{\left(i, i^{\prime}\right)}^{A}$ の多重比較検定について述べる.

$\bar{X}_{i}$.を第 $i$ 群の標本平均とし,

$$
V_{E} \equiv \frac{1}{n-k} \sum_{i=1}^{k} \sum_{j=1}^{n_{i}}\left(X_{i j}-\bar{X}_{i .}\right)^{2}
$$

とおき,

$$
T_{i i^{\prime}} \equiv \frac{\bar{X}_{i \cdot}-\bar{X}_{i^{\prime} \cdot}}{\sqrt{V_{E}\left(\frac{1}{n_{i}}+\frac{1}{n_{i^{\prime}}}\right)}} \quad\left(1 \leqq i<i^{\prime} \leqq k\right)
$$

とおく（1）の一様性の帰無仮説 $H_{0}$ の下での確率測度を $P_{0}(\cdot)$ とする. このとき, Hayter (1984) と白石 (2006) により, すべての $t>0$ に対して, 不等式

$$
T A(t) \leqq P_{0}\left(\max _{1 \leqq i<i^{\prime} \leqq k}\left|T_{i i^{\prime}}\right| \leqq t\right) \leqq T B(t)
$$

が成り立つことが解り，

$$
n_{1}=\cdots=n_{k}
$$

のとき (6) 式の等号が成り立つことが解る.

\section{[Tukey-Kramer の多重比較検定]}

\{帰無仮説 $H_{\left(i, i^{\prime}\right)}$ vs. 対立仮説 $\left.H_{\left(i, i^{\prime}\right)}^{A} \mid 1 \leqq i<i^{\prime} \leqq k\right\}$ に対する水準 $\alpha$ の多重比較検定は,

1. $i<i^{\prime}$ となるあるぺア $i, i^{\prime}$ に対して $\left|T_{i i^{\prime}}\right|>t a(k, m ; \alpha)$ ならば, 帰無仮説 $H_{\left(i, i^{\prime}\right)}$ を茟却し， 対立仮説 $H_{\left(i, i^{\prime}\right)}^{A}$ を受け入れ, $\mu_{i} \neq \mu_{i^{\prime}}$ と判定する.

2. $i<i^{\prime}$ となるあるペア $i, i^{\prime}$ に対して $\left|T_{i i^{\prime}}\right|<t a(k, m ; \alpha)$ ならば, 帰無仮説 $H_{\left(i, i^{\prime}\right)}$ を棄却しな い.

$$
P_{0}\left(\max _{1 \leqq i<i^{\prime} \leqq k}\left|T_{i i^{\prime}}\right| \leqq t\right)=1-\alpha
$$

を満たす $t$ の解を $t e\left(k, m, \lambda_{n 1}, \cdots, \lambda_{n k} ; \alpha\right)$ とし, $T B(t)=1-\alpha$ を満たす $t$ の解を $t b\left(k, m, \lambda_{n 1}, \cdots\right.$, $\left.\lambda_{n k} ; \alpha\right)$ とする. このとき, (6) より,

$$
t b\left(k, m, \lambda_{n 1}, \cdots, \lambda_{n k} ; \alpha\right) \leqq t e\left(k, m, \lambda_{n 1}, \cdots, \lambda_{n k} ; \alpha\right) \leqq t a(k, m ; \alpha)
$$

が成り立つ. (6) 式の両側の関数 $T A(t), T B(t)$ は積分範囲が単純な 2 重積分であるので, 精度保 証された数值積分が可能であるが，(7) が成り立たない場合は，(6) 式の真ん中の確率は複雑な積 分領域の $k+1$ 次元の多重積分でしか表現できない.このため近似のよい $t e\left(k, m, \lambda_{n 1}, \cdots, \lambda_{n k} ; \alpha\right)$ 
を求めることができない. Tukey-Kramer の多重比較検定法は保守的になるが，白石 (2006) は,

$$
1<\max \left\{n_{i} \mid i=1, \cdots, k\right\} / \min \left\{n_{i} \mid i=1, \cdots, k\right\} \leqq 2
$$

ならば, $t b\left(k, m, \lambda_{n 1}, \cdots, \lambda_{n k} ; \alpha\right)$ の值が $t a(k, m ; \alpha)$ の值に近いことを精度保証された数值計算で示 し, $t a(k, m ; \alpha)$ を $t e\left(k, m, \lambda_{n 1}, \cdots, \lambda_{n k} ; \alpha\right)$ の近似とみなせ, 保守性の度合いは小さいことが解った.

$T A(t)$ に関連した分布として

$$
A(t) \equiv k \int_{-\infty}^{\infty}\{\Phi(x)-\Phi(x-\sqrt{2} \cdot t)\}^{k-1} d \Phi(x)
$$

とおく.

(8)の $A(t)$ に対して,

$$
A(t)=1-\alpha \text { を満たす } t \text { の解を } a(k ; \alpha)
$$

とする.すなわち, $a(k ; \alpha)$ は分布 $A(t)$ の上側 $100 \alpha \%$ 点である. このとき, $n \rightarrow \infty$ として, $\sqrt{V_{E}} \stackrel{P}{\rightarrow} \sigma$ であるので,

$$
\lim _{n \rightarrow \infty} T A(t)=A(t)
$$

である.これにより，

$$
\lim _{m \rightarrow \infty} t a(k, m ; \alpha)=a(k ; \alpha)
$$

が成り立つ。

\section{4. ノンパラメトリック法}

分布関数 $F(x)$ は未知でもかまわないとする. 2 群間の標本観測値の中で順位をつける順位検定 が，スティール・ドゥワスによって提案されている．以下に紹介する.

$n_{i}+n_{i^{\prime}}$ 個の観測值 $X_{i 1}, \cdots, X_{i n_{i}}, X_{i^{\prime} 1}, \cdots, X_{i^{\prime} n_{i^{\prime}}}$ を小さい方から並べたときの $X_{i \ell}$ の順位を, $R_{i \ell}^{\left(i, i^{\prime}\right)}$ とする. $N_{i i^{\prime}} \equiv n_{i}+n_{i^{\prime}}$ とおき,

$$
\widehat{T}_{i i^{\prime}} \equiv \sum_{\ell=1}^{n_{i}} R_{i \ell}^{\left(i, i^{\prime}\right)}-\frac{n_{i}\left(N_{i i^{\prime}}+1\right)}{2}
$$

とおく.このとき, 白石 $(2003)$ の定理 6.2 より, (1) の $H_{0}$ の下での $\widehat{T}_{i i^{\prime}}$ の平均と分散は

$$
E_{0}\left(\widehat{T}_{i i^{\prime}}\right)=0, \quad V_{0}\left(\widehat{T}_{i i^{\prime}}\right)=\frac{n_{i} n_{i^{\prime}}\left(N_{i i^{\prime}}+1\right)}{12}
$$

で与えられる. ここで,

$$
\widehat{Z}_{i i^{\prime}} \equiv \frac{\widehat{T}_{i i^{\prime}}}{\sigma_{i i^{\prime} n}}, \quad \sigma_{i i^{\prime} n} \equiv \sqrt{\frac{n_{i} n_{i^{\prime}}\left(N_{i i^{\prime}}+1\right)}{12}}
$$

とおく. 漸近理論において

(条件 1)

$$
\lim _{n \rightarrow \infty} \frac{n_{i}}{n}=\lambda_{i}>0 \quad(i=1, \cdots, k) .
$$

を仮定する. このとき, 白石 (2008) の命題 1 より, $t>0$ に対して,

$$
A(t) \leqq \lim _{n \rightarrow \infty} P_{0}\left(\max _{1 \leqq i<i^{\prime} \leqq k}\left|\widehat{Z}_{i i^{\prime}}\right| \leqq t\right) \leqq B(t)
$$

Jpn J Biomet Vol.32, No. 1, 2011 
が成り立ち,

$$
\lambda_{i}=\frac{1}{k} \quad(1 \leqq i \leqq k) \quad \text { すなわち } \quad n_{1}=\cdots=n_{k}
$$

のとき (10) 式の等号が成り立つ. ただし,

$$
B(t) \equiv \sum_{j=1}^{k} \int_{-\infty}^{\infty} \prod_{\substack{i=1 \\ i \neq j}}^{k}\left\{\Phi\left(\sqrt{\frac{\lambda_{i}}{\lambda_{j}}} \cdot x\right)-\Phi\left(\sqrt{\frac{\lambda_{i}}{\lambda_{j}}} \cdot x-\sqrt{\frac{\lambda_{i}+\lambda_{j}}{\lambda_{j}}} \cdot t\right)\right\} d \Phi(x)
$$

とする.

\section{[漸近的なシングルステップ多重比較順位検定］}

（条件 1）を満たすと仮定する. このとき，(10) の左側の不等式より，\{帰無仮説 $H_{\left(i, i^{\prime}\right)}$ vs. 対立仮 説 $\left.H_{\left(i, i^{\prime}\right)}^{A} \mid 1 \leqq i<i^{\prime} \leqq k\right\}$ に対する水準 $\alpha$ の漸近的な多重比較検定は,

1. $i<i^{\prime}$ となるあるぺア $i, i^{\prime}$ に対して $\left|\widehat{Z}_{i i^{\prime}}\right|>a(k ; \alpha)$ ならば, 帰無仮説 $H_{\left(i, i^{\prime}\right)}$ を棄却し, 対 立仮説 $H_{\left(i, i^{\prime}\right)}^{A}$ を受け入れ, $\mu_{i} \neq \mu_{i^{\prime}}$ と判定する.

2. $i<i^{\prime}$ となるあるぺア $i, i^{\prime}$ に対して $\left|\widehat{Z}_{i i^{\prime}}\right|<a(k ; \alpha)$ ならば, 帰無仮説 $H_{\left(i, i^{\prime}\right)}$ を棄却しない.

(10) の不等式と Shiraishi (2007) の Table 1 より, $1<\max \left\{\lambda_{i}: i=1, \cdots, k\right\} / \min \left\{\lambda_{i}: i=1, \cdots, k\right\}$ $\leqq 2$ ならば，保守性の度合いは小さいことが解る.

\section{5. 閉検定手順}

$$
\begin{array}{r}
\mathcal{U} \equiv\left\{\left(i, i^{\prime}\right) \mid 1 \leqq i<i^{\prime} \leqq k\right\} \text { とお<. 帰無仮説のファミリー H } \\
\mathcal{H}=\left\{H_{\left(i, i^{\prime}\right)} \mid 1 \leqq i<i^{\prime} \leqq k\right\}=\left\{H_{\boldsymbol{v}} \mid \boldsymbol{v} \in \mathcal{U}\right\}
\end{array}
$$

と表現できる. H の要素の仮説 $H_{\left(i, i^{\prime}\right)}$ の論理積からなるすべての集合は

$$
\overline{\mathcal{H}}=\left\{\bigwedge_{\boldsymbol{v} \in V} H_{\boldsymbol{v}} \mid \emptyset \varsubsetneqq V \subset \mathcal{U}\right\}
$$

で表され, $\overline{\mathcal{H}} \mathcal{H}$ の閉包とよんでいる. 論理積 $\bigwedge_{\boldsymbol{v} \in V} H_{\boldsymbol{v}}$ についての詳しい説明は, 中内伸光 (2002) を参照すること. $\bigwedge_{\boldsymbol{v} \in \mathcal{U}} H_{\boldsymbol{v}}$ は (1) の一様性の帰無仮説 $H_{0}$ となる. さらにりでない $V \subset \mathcal{U}$ に対して

$$
\bigwedge_{\boldsymbol{v} \in V} H_{\boldsymbol{v}}: \text { 任意の }\left(i, i^{\prime}\right) \in V \text { に対して }, \mu_{i}=\mu_{i^{\prime}}
$$

は $k$ 個の母平均に関していくつかが等しいという仮説となる. $I_{1}, \cdots, I_{J}\left(I_{j} \neq \emptyset, j=1, \cdots, J\right)$ を 添え字 $\{1, \cdots, k\}$ の互いに素な部分集合の組とし, 同じ $I_{j}(j=1, \cdots, J)$ に含まれる添え字をもつ 母平均は等しいという帰無仮説を $H\left(I_{1}, \cdots, I_{J}\right)$ で表す.このとき, りでない任意の $V \subset \mathcal{U}$ に対し て，ある自然数 $J$ と上記のある $I_{1}, \cdots, I_{J}$ が存在して,

$$
\bigwedge_{\boldsymbol{v} \in V} H_{\boldsymbol{v}}=H\left(I_{1}, \cdots, I_{J}\right)
$$

が成り立つ. 
$\emptyset$ でない $V_{0} \subset \mathcal{U}$ に対して, すべての帰無仮説 $H_{\boldsymbol{v}}\left(\boldsymbol{v} \in V_{0}\right)$ が真のとき, 1 つ以上の帰無仮説 $H_{\boldsymbol{v}}\left(\boldsymbol{v} \in V_{0}\right)$ を棄却する確率が $\alpha$ 以下となる検定方式が水準 $\alpha$ の多重比較検定である. この定義 の $V_{0}$ に対して, 帰無仮説 $\bigwedge_{\boldsymbol{v} \in V_{0}} H_{\boldsymbol{v}}$ に対する水準 $\alpha$ の検定の棄却域を $A$ とし, 帰無仮説 $H_{\boldsymbol{v}}$ に 対する水準 $\alpha$ の検定の棄却域を $B_{\boldsymbol{v}}$ とすると, 帰無仮説 $\bigwedge_{\boldsymbol{v} \in V_{0}} H_{\boldsymbol{v}}$ の下で,

$$
P\left(A \cap\left(\bigcup_{\boldsymbol{v} \in V_{0}} B_{\boldsymbol{v}}\right)\right) \leqq P(A) \leqq \alpha
$$

が成り立つ.

閉検定手順は, 特定の帰無仮説を $H_{v_{0}} \in \mathcal{H}$ としとき, $\boldsymbol{v}_{0} \in V$ を満たすすべての $V(\subset \mathcal{U})$ に 対して帰無仮説 $\bigwedge_{\boldsymbol{v} \in V} H_{\boldsymbol{v}}$ の検定が水準 $\alpha$ で竦却された場合に, 多重比較検定として $H_{v_{0}}$ を棄却 する方式である.

\section{1 正規母集団での手順}

(12) より, 閉検定手順による多重比較検定のタイプ I FWER が $\alpha$ 以下となる. $T\left(I_{j}\right) \equiv$ $\max _{i<i^{\prime}, i, i^{\prime} \in I_{j}}\left|T_{i i^{\prime}}\right|(j=1, \cdots, J)$ とおき, 水準 $\alpha$ の帰無仮説 $\bigwedge_{\boldsymbol{v} \in V} H_{\boldsymbol{v}}$ に対する検定方法を具 体的にいくつか論述することができる.

\section{(I) 検出力の高い閉検定手順}

$\#(A)$ を集合 $A$ の要素の個数とし, (11) の右辺の表現 $H\left(I_{1}, \cdots, I_{J}\right)$ に対して, $M, \ell_{j}(j=$ $1, \cdots, J)$ を

$$
M \equiv M\left(I_{1}, \cdots, I_{J}\right) \equiv \sum_{j=1}^{J} \ell_{j}, \ell_{j} \equiv \#\left(I_{j}\right)
$$

とする. (3) の $T A(t)$ に対応して,

$$
T A(t \mid \ell) \equiv \ell \int_{0}^{\infty}\left[\int_{-\infty}^{\infty}\{\Phi(x)-\Phi(x-\sqrt{2} \cdot t s)\}^{\ell-1} d \Phi(x)\right] g(s) d s,
$$

とおく. ただし, $g(s)$ は (4) で定義したものとする. (5) の表記の方法より, $T A(t \mid \ell)=1-\alpha$ を 満たす $t$ の解は, $t a(\ell, m ; \alpha)$ である.

(a) $J \geqq 2$ のとき, $\ell=\ell_{1}, \cdots, \ell_{J}$ に対して

$$
\alpha(M, \ell) \equiv 1-(1-\alpha)^{\ell / M}
$$

で $\alpha(M, \ell)$ を定義する. $1 \leqq j \leqq J$ となるある整数 $j$ が存在して $t a\left(\ell_{j}, m ; \alpha\left(M, \ell_{j}\right)\right)<T\left(I_{j}\right)$ な らば帰無仮説 $\bigwedge_{\boldsymbol{v} \in V} H_{\boldsymbol{v}}$ を棄却する.

(b) $J=1\left(M=\ell_{1}\right)$ のとき, $t a(M, m ; \alpha)<T\left(I_{1}\right)$ ならば帰無仮説 $\bigwedge_{\boldsymbol{v} \in V} H_{\boldsymbol{v}}$ を革却する.

(a), (b) の方法で, $\left(i, i^{\prime}\right) \in V \subset \mathcal{U}$ を満たすすべての $V$ に対して, $\bigwedge_{\boldsymbol{v} \in V} H_{\boldsymbol{v}}$ が棄却されるとき, 多重比較検定として, $H_{\left(i, i^{\prime}\right)}$ を棄却する.

(b) の検定の有意水準が $\alpha$ であることは自明であるので, (a) の検定の有意水準は $\alpha$ であること を次の補題 1 を使って示す.

補題 $1 f_{1}(x), f_{2}(x) \geqq 0$ で, $f_{1}(x), f_{2}(x)$ は連続な単調増加関数とする. $X$ を 0 以上の值をと Jpn J Biomet Vol. 32, No. 1, 2011 
る連続型分布に従う確率変数とし， $E\left|f_{1}(X)\right|, E\left|f_{2}(X)\right|<\infty$ を仮定する. このとき,

$$
E\left\{f_{1}(X) f_{2}(X)\right\} \geqq E\left\{f_{1}(X)\right\} E\left\{f_{2}(X)\right\}
$$

が成り立つ. $f_{1}(x), f_{2}(x)$ が連続な狭義の単調増加関数ならば，上記の不等号は >である.

証明 $X$ の密度関数を $g_{X}(x)$ とする.

$$
\begin{aligned}
I T & \equiv E\left\{f_{1}(X) f_{2}(X)\right\}-E\left\{f_{1}(X)\right\} E\left\{f_{2}(X)\right\} \\
& =\int_{0}^{\infty} f_{1}(x)\left[f_{2}(x)-E\left\{f_{2}(X)\right\}\right] g_{X}(x) d x
\end{aligned}
$$

とおく.このとき, $f_{2}(x)$ が単調増加関数で連続より, $f_{2}\left(x_{0}\right)=E\left\{f_{2}(X)\right\}$ となる $x_{0}>0$ が存在 する.

ここで

$$
\begin{aligned}
I T & =-\int_{0}^{x_{0}} f_{1}(x)\left[E\left\{f_{2}(X)\right\}-f_{2}(x)\right] g_{X}(x) d x+\int_{x_{0}}^{\infty} f_{1}(x)\left[f_{2}(x)-E\left\{f_{2}(X)\right\}\right] g_{X}(x) d x \\
& =-I T_{1}+I T_{2}
\end{aligned}
$$

である.

$$
\int_{0}^{\infty}\left[f_{2}(x)-E\left\{f_{2}(X)\right\}\right] g_{X}(x) d x=0
$$

より

$$
\begin{aligned}
J T & \equiv-\int_{0}^{x_{0}}\left[f_{2}(x)-E\left\{f_{2}(X)\right\}\right] g_{X}(x) d x \\
& =\int_{x_{0}}^{\infty}\left[f_{2}(x)-E\left\{f_{2}(X)\right\}\right] g_{X}(x) d x
\end{aligned}
$$

が成り立つ. $f_{1}(x) \geqq 0$ が単調増加関数より，

$$
I T_{1} \leqq f_{1}\left(x_{0}\right) J T, I T_{2} \geqq f_{1}\left(x_{0}\right) J T
$$

これは, $I T=I T_{2}-I T_{1} \geqq 0$ を意味している.

補題 1 は, Kimball (1951)の定理を拡張して与えている.

定理 1 (a) の検定の有意水準は $\alpha$ である.

証明一般性を失うことなく $\sigma^{2}=1$ とする. $g(s)$ は $\sqrt{V_{E}}$ の密度関数である. このとき, $V_{E}, \sqrt{V_{E}}$. $T\left(I_{1}\right), \cdots, \sqrt{V_{E}} \cdot T\left(I_{J}\right)$ は互いに独立より,

$$
\begin{aligned}
P_{0}( & \left.\left(I_{j}\right) \leqq t a\left(\ell_{j}, m ; \alpha\left(M, \ell_{j}\right)\right), j=1, \cdots, J\right) \\
& =\int_{0}^{\infty} P_{0}\left(T\left(I_{j}\right) \leqq t a\left(\ell_{j}, m ; \alpha\left(M, \ell_{j}\right)\right), j=1, \cdots, J \mid \sqrt{V_{E}}=s\right) \cdot g(s) d s \\
& =\int_{0}^{\infty} P_{0}\left(\sqrt{V_{E}} \cdot T\left(I_{j}\right) \leqq s \cdot t a\left(\ell_{j}, m ; \alpha\left(M, \ell_{j}\right)\right), j=1, \cdots, J \mid \sqrt{V_{E}}=s\right) \cdot g(s) d s \\
& =\int_{0}^{\infty}\left\{\prod_{j=1}^{J} P_{0}\left(\sqrt{V_{E}} \cdot T\left(I_{j}\right) \leqq s \cdot \operatorname{ta}\left(\ell_{j}, m ; \alpha\left(M, \ell_{j}\right)\right)\right)\right\} \cdot g(s) d s
\end{aligned}
$$

が導かれる. 


$$
\begin{aligned}
& f_{1}(s) \equiv P_{0}\left(\sqrt{V_{E}} \cdot T\left(I_{1}\right) \leqq s \cdot t a\left(\ell_{1}, m ; \alpha\left(M, \ell_{1}\right)\right)\right), \\
& f_{2}(s) \equiv \prod_{j=2}^{J} P_{0}\left(\sqrt{V_{E}} \cdot T\left(I_{j}\right) \leqq s \cdot t a\left(\ell_{j}, m ; \alpha\left(M, \ell_{j}\right)\right)\right)
\end{aligned}
$$

とおき, 補題 1 を適用すると,

$$
\begin{aligned}
(15) \geqq & \int_{0}^{\infty} P_{0}\left(\sqrt{V_{E}} \cdot T\left(I_{1}\right) \leqq s \cdot t a\left(\ell_{1}, m ; \alpha\left(M, \ell_{1}\right)\right)\right) \cdot g(s) d s \\
& \cdot \int_{0}^{\infty} \prod_{j=2}^{J} P_{0}\left(\sqrt{V_{E}} \cdot T\left(I_{j}\right) \leqq s \cdot t a\left(\ell_{j}, m ; \alpha\left(M, \ell_{j}\right)\right)\right) \cdot g(s) d s
\end{aligned}
$$

を得る. 以下帰納法的に

$$
(15) \geqq \prod_{j=1}^{J} \int_{0}^{\infty} P_{0}\left(\sqrt{V_{E}} \cdot T\left(I_{j}\right) \leqq s \cdot t a\left(\ell_{j}, m ; \alpha\left(M, \ell_{j}\right)\right)\right) \cdot g(s) d s
$$

が導かれる. Hayter (1984)の定理を使つて

$$
P_{0}\left(\sqrt{V_{E}} \cdot T\left(I_{j}\right) \leqq s \cdot t a\left(\ell_{j}, m ; \alpha\left(M, \ell_{j}\right)\right)\right) \geqq A\left(s \cdot t a\left(\ell_{j}, m ; \alpha\left(M, \ell_{j}\right)\right) \mid \ell_{j}\right)
$$

の関係より,

$$
\begin{aligned}
\int_{0}^{\infty} & P_{0}\left(\sqrt{V_{E}} \cdot T\left(I_{j}\right) \leqq s \cdot t a\left(\ell_{j}, m ; \alpha\left(M, \ell_{j}\right)\right)\right) \cdot g(s) d s \\
& \geqq \int_{0}^{\infty} A\left(s \cdot \operatorname{ta}\left(\ell_{j}, m ; \alpha\left(M, \ell_{j}\right)\right) \mid \ell_{j}\right) g(s) d s \\
& =T A\left(\operatorname{ta}\left(\ell_{j}, m ; \alpha\left(M, \ell_{j}\right)\right) \mid \ell_{j}\right) \\
& =1-\alpha\left(M, \ell_{j}\right) \\
& =(1-\alpha)^{\ell_{j} / M}
\end{aligned}
$$

を得る.ただし，(8)の $A(t)$ に対応して,

$$
A(t \mid \ell) \equiv \ell \int_{-\infty}^{\infty}\{\Phi(x)-\Phi(x-\sqrt{2} \cdot t)\}^{\ell-1} d \Phi(x)
$$

とおく.(16), (17) を使って,

$$
\begin{aligned}
& P_{0}\left(\text { ある } j \text { が存在して, } T\left(I_{j}\right)>\operatorname{ta}\left(\ell_{j}, m ; \alpha\left(M, \ell_{j}\right)\right)\right) \\
& \quad=1-P_{0}\left(T\left(I_{j}\right) \leqq t a\left(\ell_{j}, m ; \alpha\left(M, \ell_{j}\right)\right), j=1, \cdots, J\right) \\
& \quad \leqq 1-\prod_{j=1}^{J}\left\{(1-\alpha)^{\ell_{j} / M}\right\} \\
& \quad=\alpha
\end{aligned}
$$

が成り立つ. ここで, 帰無仮説 $\bigwedge_{\boldsymbol{v} \in V} H_{\boldsymbol{v}}$ に対する (a) の検定は, 有意水準 $\alpha$ である.

定理 1 より, (I) は水準 $\alpha$ の多重比較検定である.

永田・吉田 (1997) で紹介されているテューキー・ウェルシュの方法と丹後・小西 (2010) で紹 介されている REGW 法は正規分布論の閉検定手順としてよく使われる.これら 2 つの方法に沿つ Jpn J Biomet Vol. 32, No.1, 2011 
た手法を紹介する. このために, $I(I \subset\{1, \cdots, k\})$ に含まれる添え字をもつ母平均は等しいとい う帰無仮説を $H(I)$ で表し， $\imath \equiv \#(I)$ とおく.さらに, $k \geqq 4$ とし,

$$
\alpha^{*}(\imath) \equiv \begin{cases}1-(1-\alpha)^{\imath / k} & (2 \leqq \imath \leqq k-2) \\ \alpha & (\imath=k-1, k)\end{cases}
$$

によって $\alpha^{*}(\imath)$ を定義する.

(II) テューキー・ウェルシュの方法

$$
c_{\imath} \equiv \begin{cases}\max \left\{t a\left(\imath, m ; \alpha^{*}(\imath)\right), c_{\imath-1}\right\} & (3 \leqq \imath \leqq k) \\ t a\left(2, m ; \alpha^{*}(2)\right) & (\imath=2)\end{cases}
$$

とおき, $c_{\imath}<T(I)$ ならば帰無仮説 $H(I)$ を棄却する. この方法で $i, i^{\prime} \in I$ を満たすすべての $I に$ 対して $H(I)$ が棄却されるとき, 多重比較検定として, $H_{\left(i, i^{\prime}\right)}$ を棄却する.

\section{(III) REGW 法}

$t a\left(\imath, m ; \alpha^{*}(\imath)\right)<T(I)$ ならば帰無仮説 $H(I)$ を棄却する. この方法で $i, i^{\prime} \in I$ を満たすすべての $I$ に対して $H(I)$ が棄却されるとき, 多重比較検定として, $H_{\left(i, i^{\prime}\right)}$ を棄却する.

帰無仮説 $\bigwedge_{\boldsymbol{v} \in V} H_{\boldsymbol{v}}$ に対する (II), (III) の検定方式の有意水準が $\alpha$ であることを, 補題 1 を使つ て (19) と同様の方法によって示せる.

閉検定手順 (I) から (III) において, $T\left(I_{j}\right), T(I)$ のかわりにそれぞれ

$$
\begin{aligned}
T_{S}\left(I_{j}\right) & =\sum_{i \in I_{j}} n_{i}\left(\bar{X}_{i}-\bar{X}_{I_{j}}\right)^{2} / V_{E}, \\
T_{S}(I) & =\sum_{i \in I} n_{i}\left(\bar{X}_{i} \cdot-\bar{X}_{I}\right)^{2} / V_{E}
\end{aligned}
$$

を使っても閉検定手順が行える. ただし，

$$
\bar{X}_{I} \equiv \sum_{i \in I} n_{i} \bar{X}_{i} \cdot / \sum_{i \in I} n_{i}
$$

とする. この場合, (I) の検出力の高い閉検定手順においては, $t a\left(\ell_{j}, m ; \alpha\left(M, \ell_{j}\right)\right)<T\left(I_{j}\right), t a(M$, $m ; \alpha)<T\left(I_{1}\right)$ をそれぞれ $F_{m}^{\ell_{j}-1}\left(\alpha\left(M, \ell_{j}\right)\right)<T_{S}\left(I_{j}\right), F_{m}^{M-1}(\alpha)<T_{S}\left(I_{1}\right)$ に置き換えればよい. た だし, 自由度 $\left(m_{1}, m_{2}\right)$ の $\mathrm{F}$ 分布の上側 $100 \alpha \%$ 点を $F_{m_{2}}^{m_{1}}(\alpha)$ とする. また, (II) のテューキー・ ウェルシュの方法と (III) の REGW 法においては, $t a\left(\imath, m ; \alpha^{*}(\imath)\right)$ を $F_{m}^{2-1}\left(\alpha^{*}(\imath)\right)$ に置き換えれば よい.

$$
\ell_{j}=\imath=\ell \text { のさ }
$$

$$
1-(1-\alpha)^{\ell / M} \geqq 1-(1-\alpha)^{\ell / k}
$$

の関係により，(I) の閉検定手順の帰無仮説 $\bigwedge_{\boldsymbol{v} \in V} H_{\boldsymbol{v}}$ に関する棄却域が (II) と (III) の棄却域を 含むことになり，(I) の閉検定手順が，テューキー・ウェルシュの方法や REGW 法よりも一様に 検出力が高いこととなる. 


\section{2 ノンパラメトリック手順}

$\widehat{Z}\left(I_{j}\right) \equiv \max _{i<i^{\prime}, i, i^{\prime} \in I_{j}}\left|\widehat{Z}_{i i^{\prime}}\right|(j=1, \cdots, J)$ とおき, 水準 $\alpha$ の帰無仮説 $\bigwedge_{\boldsymbol{v} \in V} H_{\boldsymbol{v}}$ に対する漸近 的な検定方法を具体的にいくつか論述することができる.

\section{(IV) 検出力の高い閉検定手順}

$M, \ell_{j}(j=1, \cdots, J)$ を(13) で定義したものとする. (9) の表記の方法より，(18)の $A(t \mid \ell)$ に対 して, $A(t \mid \ell)=1-\alpha$ を満たす $t$ の解は, $a(\ell ; \alpha)$ である.

(A) $J \geqq 2$ のとき, $\ell=\ell_{1}, \cdots, \ell_{J}$ に対して,$\alpha(M, \ell)$ を (14) で定義したものとする. $1 \leqq j \leqq J$ となるある整数 $j$ が存在して $a\left(\ell_{j} ; \alpha\left(M, \ell_{j}\right)\right)<\widehat{Z}\left(I_{j}\right)$ ならば帰無仮説 $\bigwedge_{\boldsymbol{v} \in V} H_{\boldsymbol{v}}$ を棄却する.

(B) $J=1\left(M=\ell_{1}\right)$ のとき, $a(M ; \alpha)<\widehat{Z}\left(I_{1}\right)$ ならば帰無仮説 $\bigwedge_{\boldsymbol{v} \in V} H_{\boldsymbol{v}}$ を棄却する.

(A), (B) の方法で, $\left(i, i^{\prime}\right) \in V$ を満たすすべての $V$ に対して, $\bigwedge_{\boldsymbol{v} \in V} H_{\boldsymbol{v}}$ が棄却されるとき, 多 重比較検定として, $H_{\left(i, i^{\prime}\right)}$ を棄却する.

(B) の検定の有意水準が漸近的に $\alpha$ であることは自明であるので, (A) の検定の有意水準は漸 近的に $\alpha$ であることを示す.

定理 2 （条件 1)の下で, (A) の検定の有意水準は漸近的に $\alpha$ である.

証明 $\widehat{Z}\left(I_{1}\right), \cdots, \widehat{Z}\left(I_{J}\right)$ は互いに独立より,

$$
\lim _{n \rightarrow \infty} P_{0}\left(\widehat{Z}\left(I_{j}\right) \leqq a\left(\ell_{j} ; \alpha\left(M, \ell_{j}\right)\right), j=1, \cdots, J\right)=\prod_{j=1}^{J}\left\{\lim _{n \rightarrow \infty} P_{0}\left(\widehat{Z}\left(I_{j}\right) \leqq a\left(\ell_{j} ; \alpha\left(M, \ell_{j}\right)\right)\right)\right\}
$$

を得る. (10) の左側の不等式を使って,

$$
\begin{aligned}
(21) & \geqq \prod_{j=1}^{J} A\left(a\left(\ell_{j} ; \alpha\left(M, \ell_{j}\right)\right) \mid \ell_{j}\right) \\
& =\prod_{j=1}^{J}\left(1-\alpha\left(M, \ell_{j}\right)\right) \\
& =\prod_{j=1}^{J}\left\{(1-\alpha)^{\ell_{j} / M}\right\} \\
& =1-\alpha
\end{aligned}
$$

を得る. (22) を使って,

$$
\begin{aligned}
& \lim _{n \rightarrow \infty} P_{0}\left(\text { ある } j \text { が存在して, } \widehat{Z}\left(I_{j}\right)>a\left(\ell_{j} ; \alpha\left(M, \ell_{j}\right)\right)\right) \\
& \quad=1-\lim _{n \rightarrow \infty} P_{0}\left(\widehat{Z}\left(I_{j}\right) \leqq a\left(\ell_{j} ; \alpha\left(M, \ell_{j}\right)\right), j=1, \cdots, J\right) \\
& \quad \leqq \alpha
\end{aligned}
$$

が成り立つ.ここで, (A) の検定は, 有意水準 $\alpha$ である.

定理 2 より，(IV) は水準 $\alpha$ の漸近的な多重比較検定である.

テューキー・ウェルシュの方法と REGW 法は正規分布論の閉検定手順である. これら 2 つ 
方法に沿つた順位手法を紹介する. このために, $I(I \subset\{1, \cdots, k\})$ に含まれる添え字をもつ母平 均は等しいという帰無仮説を $H(I)$ で表し， $\imath \equiv \#(I)$ とおく. さらに, $k \geqq 4$ とし, $(20)$ によ て $\alpha^{*}(\imath)$ を定義する.

\section{（V）テューキー・ウェルシュの順位手法}

$$
c_{\imath} \equiv \begin{cases}\max \left\{a\left(\imath ; \alpha^{*}(\imath)\right), c_{\imath-1}\right\} & (3 \leqq \imath \leqq k) \\ a\left(2 ; \alpha^{*}(2)\right) & (\imath=2)\end{cases}
$$

とおき, $c_{2}<\widehat{Z}(I)$ ならば帰無仮説 $H(I)$ を棄却する. この方法で $i, i^{\prime} \in I$ を満たすすべての $I に$ 対して $H(I)$ が棄却されるとき, 漸近的な多重比較検定として, $H_{\left(i, i^{\prime}\right)}$ を棄却する.

\section{(VI) REGW 順位手法}

$a\left(\imath ; \alpha^{*}(\imath)\right)<\widehat{Z}(I)$ ならば帰無仮説 $H(I)$ を棄却する. この方法で $i, i^{\prime} \in I$ を満たすすべての $I に$ 対して $H(I)$ が棄却されるとき, 漸近的な多重比較検定として, $H_{\left(i, i^{\prime}\right)}$ を棄却する.

$\left\{X_{i j} \mid j=1, \cdots, n_{i}, i \in I\right\}$ の中での $X_{i j^{\prime}}$ の順位を $R_{i j^{\prime}}(I)$ とする. 閉検定手順 (IV) から (VI) において, $\widehat{Z}\left(I_{j}\right), \widehat{Z}(I)$ のかわりにそれぞれ

$$
\begin{aligned}
Z_{R}\left(I_{j}\right) & \equiv \frac{12}{n\left(I_{j}\right)\left\{n\left(I_{j}\right)+1\right\}} \sum_{i \in I_{j}} n_{i}\left(\bar{R}_{\left.i \cdot\left(I_{j}\right)-\frac{n\left(I_{j}\right)+1}{2}\right)^{2},},\right. \\
Z_{R}(I) & \equiv \frac{12}{n(I)\{n(I)+1\}} \sum_{i \in I} n_{i}\left(\bar{R}_{i}(I)-\frac{n(I)+1}{2}\right)^{2}
\end{aligned}
$$

を使っても閉検定手順が行える. ただし，

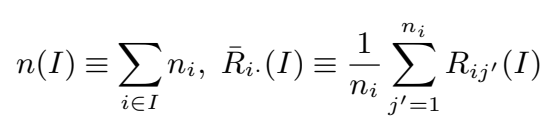

とする. この場合, (IV) の検出力の高い閉検定手順においては, $a\left(\ell_{j} ; \alpha\left(M, \ell_{j}\right)\right)<\widehat{Z}\left(I_{j}\right), a(M ; \alpha)<$ $\widehat{Z}\left(I_{1}\right)$ をそれぞれ $\chi_{\ell_{j}-1}^{2}\left(\alpha\left(M, \ell_{j}\right)\right)<Z_{R}\left(I_{j}\right), \chi_{M-1}^{2}(\alpha)<Z_{R}\left(I_{1}\right)$ に置き換えればよい. ただし, 自 由度 $\ell$ の $\chi^{2}$ 分布の上側 $100 \alpha \%$ 点を $\chi_{\ell}^{2}(\alpha)$ とする. また, $(\mathrm{V})$ のテューキー・ウェルシュの方法 と $(\mathrm{VI})$ の REGW 法においては, $a\left(\imath ; \alpha^{*}(\imath)\right)$ を $\chi_{\imath-1}^{2}\left(\alpha^{*}(\imath)\right)$ に置き換えればよい.

5.1 節で述べた正規理論の場合と同様に，(IV) の閉検定手順の帰無仮説 $\bigwedge_{\boldsymbol{v} \in V} H_{\boldsymbol{v}}$ に関する棄却 域が (V) と (VI) の棄却域を含むことになり, (IV) の閉検定手順が, テューキー・ウェルシュの 順位手法や REGW 順位手法よりも一様に検出力が高いこととなる.

\section{6. 解 析 例}

サルコイドーシスは原因不明の肉芽種病である. SACE (serum angiotensin-converting enzyme: 血清アンジオテンシン変換酵素) 分析評価法は活性類肉腫症の診断に有効であると言われている. この統計解析の目的は SACE 值が肉芽種症に関する症状で分類された群 \{第 1 群：病状が重いもし くは進んでいる人, 第 2 群：病状が安定している人, 第 3 群: 病状が回復した人, 第 4 群: 病気に かかったことのない人\} において差異があるかを判定することである. デー夕は, Daniel (1987) の 336 ページに掲載されている等しい群サイズ 400 から, ランダムに, それぞれ, $15,15,20,22$ 
個採つたものを白石 (2008) の表 9 にまとめている.

以下, 計算機を使用し, 群サイズが

$$
n_{1}=15, n_{2}=15, n_{3}=20, n_{4}=22
$$

である白石 (2008) の表 9 のデータを解析する.

杉山等 (2007) の第 3 章の項目「分布探索による推測法の選択方式」で紹介されている分布探索 方式を使うと, データが最も近い分布は, 白石 (2003) 第 5 章に載せられている小さな異常值をも つ混合分布となった．これにより，順位に基づくノンパラメトリック法を使って解析する. 杉山 等 (2007) の第 3 章で紹介されている順位点推定值は,

相対処理効果: $\hat{\tau}_{1}=65.032, \hat{\tau}_{2}=4.486, \hat{\tau}_{3}=-32.419, \hat{\tau}_{4}=-17.927$, 全平均: $\tilde{\nu}=110.2$,

4 群の平均: $\hat{\mu}_{1}=175.2, \hat{\mu}_{2}=114.7, \hat{\mu}_{3}=77.8, \hat{\mu}_{4}=92.3$

となった．統計量 $\widehat{Z}_{i i^{\prime}}$ の值として

$$
\widehat{Z}_{12}=4.666, \widehat{Z}_{13}=5.000, \widehat{Z}_{14}=5.104, \widehat{Z}_{23}=4.833, \widehat{Z}_{24}=4.021, \widehat{Z}_{34}=-2.972
$$

を得た．第 4 節で紹介した水準 0.01 の漸近的なシングルステップ多重比較順位検定を使うと,

$$
a(4 ; 0.01)=3.113<\left|\widehat{Z}_{12}\right|,\left|\widehat{Z}_{13}\right|,\left|\widehat{Z}_{14}\right|,\left|\widehat{Z}_{23}\right|,\left|\widehat{Z}_{24}\right|, \quad a(4 ; 0.01)>\left|\widehat{Z}_{34}\right|
$$

となり，帰無仮説 $H_{(3,4)}=H(\{3,4\})$ だけが棄却されない．このため，(IV) のノンパラメトリッ ク閉検定手順を使って水準 $\alpha=0.01$ で解析する. 表 2 と表 3 を使って,

(i) $a(4 ; \alpha(4,4))=3.113<5.104=\widehat{Z}(\{1,2,3,4\})$ より, $M=\ell_{1}=4$ の $H(\{1,2,3,4\})$ は棄却さ れる。

(ii) $a(2 ; \alpha(4,2))=2.806<4.666=\left|\widehat{Z}_{12}\right|=\widehat{Z}(\{1,2\})$ より, $M=4, \ell_{1}=\ell_{2}=2$ の $H(\{1,2\},\{3$, $4\})$ は棄却される. 同様に, $H(\{1,3\},\{2,4\}), H(\{1,4\},\{2,3\})$ もすべて棄却される.

表 2. $k=4$ のとき, ステップワイズ法で検定される帰無仮説 $H\left(I_{1}, \cdots, I_{J}\right)$

\begin{tabular}{cccc}
\hline$M$ の値 & \multicolumn{3}{c}{$H\left(I_{1}, \cdots, I_{J}\right)$} \\
\hline 4 & $H(\{1,2,3,4\})$, & $H(\{1,2\},\{3,4\})$, & $H(\{1,3\},\{2,4\})$, \\
& $H(\{1,4\},\{2,3\})$ & & \\
3 & $H(\{1,2,3\})$, & $H(\{1,2,4\})$, & $H(\{2,3,4\})$ \\
2 & $H(\{1,2\})$ & $H(\{1,3\})$ & $H(\{1,4\})$ \\
& $H(\{2,3\})$ & $H(\{2,4\})$ & $H(\{3,4\})$ \\
\hline
\end{tabular}

表 3. $\alpha=0.01$ のときの $a(\ell ; \alpha(M, \ell))$ の值

\begin{tabular}{cccc}
\hline$M \backslash \ell$ & 2 & 3 & 4 \\
\hline 4 & 2.806 & 3.004 & 3.113 \\
3 & 2.712 & 2.913 & \\
2 & 2.576 & & \\
\hline
\end{tabular}


(iii) $a(3 ; \alpha(3,3))=2.913<5.000=\widehat{Z}(\{1,2,3\})$ より, $H(\{1,2,3\})$ は㶳却される. 同様に, $H(\{1$, $2,4\}), H(\{2,3,4\})$ もすべて棄却される.

(iv) $a(2 ; \alpha(2,2))=2.576<4.666=\widehat{Z}(\{1,2\})$ より, $H(\{1,2\})$ は茟却される. 同様に, $H(\{1,3\})$ ， $H(\{1,4\}), H(\{2,3\}), H(\{2,4\}), H(\{3,4\})$ もすべて棄却される.

上記の (i)-(iv) より, 表 2 のすべての帰無仮説が棄却され, 水準 $\alpha=0.01$ の (IV) のノンパラメ トリック閉検定手順により, $1 \leqq i<i^{\prime} \leqq 4$ となるすべての $\left(i, i^{\prime}\right)$ に対して $\mu_{i} \neq \mu_{i^{\prime}}$ と結論できる.

\section{7. おしまいに}

分散の等しい多群モデルにおけるすべての平均相違の多重比較検定法は, 正規分布の下で, Tukey (1953) と Kramer (1956) によって提案され, 現在ではテューキー・クレーマー (Tukey-Kramer) 法とよばれている. このテューキー・クレーマー法の検定統計量の分布は (6) 式のように下から 抑える分布 $T A(t)$ と上から抑える分布 $T B(t)$ によって挟まれる. (6) の右側の不等号は等号と書 かれた文献があったが, 白石 (2006) が不等号が正しいことを証明した. 現在も等号が正しいよう に書かれている本が存在する. テューキー・クレーマー法は保守的な手法になっているが, (6) の 両方の不等式と 2 重積分の精度保証された数値計算によって, 保守度が小さいことを白石 $(2006)$ が示した. 順位に基づく分布に依らない多重比較検定法についても, 漸近的に (6) と同様の不等式 (10) が成り立ち, 順位による漸近的な多重比較検定法の保守度が小さいことを, Shiraishi (2007) と白石 (2008) は示した. また, 全体順位を使う Dunn (1964) の検定法が多くの和書に書かれてき たが, Dunn (1964) の検定法が多重比較検定になっていないことを, Oude Voshaar (1980) と Hsu (1996) が指摘している. ノンパラメトリック多重比較では, 全体順位ではなく 2 群間の中での順 位を使う方法が正しい。この論文では，それらのシングルステップ法を基にした閉検定手順につ いて，正規母集団での手順とノンパラメトリック手順を新たに提案し，Kimball (1951)の定理を 拡張した補題 1 を使って, 多重比較検定になっていることを証明した. さらに，提案した閉検定 手順は，テューキー・ウェルシュの方法や REGW 法よりも一様に検出力が高いことを示した.

\section{謝辞}

本論文の修正にあたり, 貴重なご指摘と有益なご助言をいただいた 2 人の査読者に大変感謝致 します. 本研究は, 日本学術振興会科学研究費補助金基盤研究 (C)(課題番号 20540126) 及び 2010 年度南山大学パッへ研究奨励金 I-A-2 の援助を受けたものである.

\section{参考文献}

Daniel, W. W. (1987). Biostatistics: A Foundation for Analysis in the Health Sciences. Fifth Edition. Wiley and Sons.

Dunn, O. J. (1964). Multiple comparisons using rank sums. Technometrics 6. 241-252.

Hayter, A. J. (1984). A proof of the conjecture that the Tukey-Kramer multiple comparisons procedure is conservative. Annals of Statistics 12. 61-75. 
Hochberg, Y. and Tamhane, A. C. (1987). Multiple Comparisons Procedures. Wiley and Sons.

Hsu, J. C. (1996). Multiple Comparisons-Theory and Methods. Chapman and Hall.

Kimball, A. W. (1951). On dependent tests of significance in the analysis of variance. Annals of Mathematical Statistics 22. 600-602.

Kramer, C. Y. (1956). Extension of multiple range tests to goup means with unequal numbers of replications. Biometrics 8. 75-86.

中内伸光 (2002). 数学の基礎体力をつけるためのろんりの練習帳. 共立出版.

永田 靖, 吉田道弘 (1997). 統計的多重比較法の基礎. サイエンティスト社.

Oude Voshaar, J. H. (1980). (k-1)-mean significance levels of nonparametric multiple comparisons procedures. Ann of Statistics 8. 75-86.

白石高章 (2003). 統計科学一パラメトリック, ノンパラメトリック, セミパラメトリックの基礎 から, Esoft, Excelによるデー夕解析まで. 日本評論社.

白石高章 (2006). Tukey-Kramer 法に関連した分布の上界. 計算機統計学会 和文誌 19. 77-87.

白石高章 (2008). 多群モデルにおけるウィルコクソンの順位和に基づくノンパラメトリック同時 信頼区間. 応用統計学 37. 125-150.

Shiraishi, T. (2007). Multiple comparisons based on R-estimators in the one-way layout. Journal of the Japan Statistical Society 37, 157-174.

杉山高一, 藤越康祝, 杉浦成昭, 国友直人 編集 (2007). 統計デー夕科学事典. 朝倉書店.

丹後俊郎, 小西貞則 編集 (2010). 医学統計学の事典. 朝倉書店.

Tukey, J. W. (1953). The Problem of Multiple Comparisons. The Collected Works of John W. Tukey, J. W. (1994), Volume VIII. Multiple Comparisons. Chapman and Hall. 